This is an electronic reprint of the original article. This reprint may differ from the original in pagination and typographic detail.

Author(s): Kulbok-Lattik, Egge

Title: $\quad$ The sovietization of Estonian community houses (Rahvamaja): Soviet guidelines

Year: $\quad 2014$

Version:

Please cite the original version:

Kulbok-Lattik, E. (2014). The sovietization of Estonian community houses (Rahvamaja): Soviet guidelines. Acta Historica Tallinnensia, 20(1), 157-190. https://doi.org/10.3176/hist.2014.1.06

All material supplied via JYX is protected by copyright and other intellectual property rights, and duplication or sale of all or part of any of the repository collections is not permitted, except that material may be duplicated by you for your research use or educational purposes in electronic or print form. You must obtain permission for any other use. Electronic or print copies may not be offered, whether for sale or otherwise to anyone who is not an authorised user. 


\title{
THE SOVIETIZATION OF ESTONIAN COMMUNITY HOUSES (RAHVAMAJA): SOVIET GUIDELINES
}

\author{
Egge KULBOK-LATTIK
}

Department of Social Sciences and Philosophy University of Jyväskylä, P.O. Box 35, 40014, Finland; egge.kulboklattik@gmail.com

Estonian Community houses were built in towns and the countryside by local people, who joined cultural and other societies since the second half of the 19th century. These cultural centers supported the process of Estonian state building. During the years of the first Estonian independent state (1918-1940), the network of community houses was set up by the state.

After the invasion of the Baltic states by the Soviet Union in 1940, extensive restructuring or sovietization of the Estonian public administration, economy and culture, began. The article examines the sovietization process of Estonian community houses, i.e., how they were turned into the ideological tools of Soviet totalitarian propaganda.

\section{INTRODUCTION}

Estonian community houses, with roots in the 19th century tradition of grassroots-level social activism, were built in towns and the countryside by ordinary ${ }^{1}$ people, who joined cultural, agricultural, temperance and other societies. These houses became the pillars of the emerging Estonian civil society and public sphere, by offering space for new cultural practices of Estonians, such as singing in many-voiced choirs, playing music in brass bands, acting in theater plays, establishing local libraries, organizing lectures, as well as hosting public festivities of local communities. Community houses, with their cultural practices, supported the process of state building by bringing the ideas of the Estonian elite to grassroots level. During the years of the first Estonian independent state (1918-1940), the network of community houses was set up by the state. ${ }^{2}$ The Law on Community

1 Ordinary people are understood as "little men", as opposed to the "great" or elite.

2 New cultural practices of Estonians were borrowed from the Baltic-German aristocracy, in the light of postcolonial theories. See Kulbok-Lattik, E. Estonian community houses as local tools for development. - Nordisk Kulturpolitisk Tidsskrift, 2012, 2, 253-283. 
Houses was adopted in 1931, which stated the aim and objectives of community houses as follows: ${ }^{3}$

Article 1: The aim of a community house is to be a center for cultural and free educational activities and a home for educational and social associations in its area of operation.

Article 2: Community houses should have rooms for libraries, reading rooms, studios, rooms for lectures and public meetings, rooms for singing, musical and theatrical rehearsals as well as rooms for physical training and other educational activities (RT 1931, 53). ${ }^{4}$

By 1940, there were approximately 500 community houses all over Estonia, ${ }^{5}$ which operated as local institutions for the development of Estonian cultural policy, being the expression of the socio-economic and cultural vitality of Estonian rural regions.

In June, 1940, after the invasion of the Baltic states by the Soviet Union, the extensive restructuring or sovietization of the public administration, economy, with the nationalization of private property, propagandistic land reform and mass deportations began. ${ }^{6}$ Sovietization was carried out in all spheres of life. The sovietization process of community houses meant the importation of the Soviet cultural canon (norms, values) and cultural policy model. Bottom-up initiatives by societies were prohibited, community houses (as well as all other private cultural enterprises) were closed and their property was expropriated. As all cultural organizations became state-operated and guided, the Soviet cultural policy model was fully implemented in Estonia. The network of community houses was filled with Red Corners ${ }^{7}$ and obligatory political training of the population took place. The new content for cultural policy came from the manipulative rhetoric of a totalitarian state shaping the Homo Soveticus, which resulted in strong centralization, guidelines being issued to the community houses, and censorship.

http:/www.idunn.no/ts/nkt/2012/02/estonian community houses as local tools for the developmen; Jansen, E. Estonians in the Changing World: From Estate Society to Civil Society. Eesti Ajaloo Arhiiv, Tartu, 2007; Karu, E. On the Development of the Association Movement and Its SocioEconomic Background in the Estonian Countryside. (Acta Universitatis Stockholmiensis, Studia Baltica Stockholmiensia, 2.) Stockholm, 1985.

3 Author's translation.

${ }^{4}$ Kurvits, A. Rahvamaja: käsiraamat rahvamajade asutamise ja ülalpidamise, ruumide ja ümbruse korraldamise ja kaunistamise ning tegevuse juhtimise ja edendamise alal [Community House: Handbook for the Foundation and Management of Community Houses]. Kirjastus kooperatiiv, Tallinn, 1935, 72 .

5 Uljas, J. Rahvamajad Eestis, 1920-1940 [Community Houses in Estonia, 1920-1940]. E. Vilde nim. Tallinna Pedagoogiline Instituut, Tallinn, 1987, 19, 28.

6 Aigi Rahi-Tamm has mapped Estonian deportations in her PhD dissertation: http://dspace.utlib.ee/ dspace/bitstream/handle/10062/528/RahiTamm.pdf?sequence=5; http://okupatsioon.ee/en, see also http:/www.riigikogu.ee/public/Riigikogu/TheWhiteBook.pdf

7 Red Corners were special areas (pinboards or table with books) set up by Soviet authorities in public places in Soviet Russia with the aim to disseminate Marxist ideas and promote the Communist classics. 


\begin{abstract}
Aims of the article
In this article I analyse the sovietization process of Estonian community houses, i.e., how they were turned into the ideological tools of Soviet propaganda. ${ }^{8}$ To do this, I examine: (1) the formation of the Soviet cultural canon to identify its targets, features and also the model of the Soviet cultural policy; (2) the process of how the free-initiative amateur art and educational activities in community houses were restructured into subordinate cultural institutions; (3) the methodical guidelines provided by state bodies as tools of coercion, control and censorship in making Estonian community houses function as centers of political education.

Empirical data, archival materials and methodical guidelines (published from 1940 onwards) are used and analysed. In order to contextualize the Soviet state practices I use the term sovietization. The description of the role of the state in cultural policy is based on the theoretical framework of Hillman-Chartrand and McCaughey's (1989) concept of cultural policy models. ${ }^{9}$ The methods of the article are: the case study and historical analysis, and the focus - cultural policy research, which is interdisciplinary research on society, comprising cultural theory, social history, ethnology, political science, etc. In respect of the development of Estonian state practices in cultural policy, the paper helps to reveal certain facets of socioeconomic developments and macro-historical path-dependencies of Estonia (as well as the other Baltic states). Given the large amount written on Soviet Russia in this context (put in lots of references in a big line) I do not directly deal with this topic here.
\end{abstract}

\title{
SOVIETIZATION, SOVIET CULTURAL CANON AND CULTURAL POLICY MODEL
}

Sovietization is conceptualized as the process of exporting the Soviet model of a state. The process of sovietization, as historians Tannberg (2007), Zubkova (2007), Mertelsmann (2012) explain, implied more than a mere political takeover -

8 Propaganda is the dissemination of information - facts, arguments, rumors, half-truths, or lies to influence public opinion. Propaganda is the more or less systematic effort to manipulate other people's beliefs, attitudes, or actions by means of symbols (words, gestures, banners, monuments, music, clothing, insignia, hairstyles, designs on coins and postage stamps, and so forth): Smith, B. L., Lasswell, H. D., Casey, R. D. Propaganda, Communication, and Public Opinion: A Comprehensive Reference Guide. Princeton University Press, 1946, vii, 435.

9 The concept of the cultural policy model helps to identify the way how the state's interference in culture is organized in different states and political systems. Various cultural policy models are described and defined by Hillmann-Chartrand, H., McCaughey, C. The arm's length principle and the arts: an international perspective - past, present and future. - In: Who's to Pay? for the Arts: The International Search for Models of Support. Eds M. C. Cummings Jr, M. Davidson Schuster. American Council for the Arts, N.Y.C., 1989. 
it also meant social, economic and cultural restructuring. ${ }^{10}$ While institutional restructuring took only a few years, the restructuring of society and culture took much longer. The population had to be "re-educated" and a new, socialist elite had to be created. According to Mertelsmann, ${ }^{11}$ the basic model of sovietization consisted of Lenin's and Stalin's Cultural Revolution, forced collectivization of agriculture and the start of the campaign of industrialization and the planned or command economy. In general, Soviet state practices were coercive and violent as Gerlach and Werth $(2009,133-179)^{12}$ explain: class struggle and terror, oppression of the "enemies" of the Soviet state, (kulaks, priests, bourgeois specialists), attempts to achieve total control over the population, nationalization of private property, strict censorship, political agitation, the provision a set of canonized cultural norms were some of the key elements of sovietization. While Soviet state practices did change over time (influenced by the development of its own inner policies as well as external pressure through the Cold War), the main structures of the state model of the USSR established in the 1930s persisted until its collapse in 1991.

In terms of culture, censorship and indoctrination ${ }^{13}$ of the Soviet values, which the vast majority of population perceived as unfamiliar and odd, took place. In order to 're-educate' the population of the occupied territories, the Soviet cultural canon (invented tradition bearing Soviet values) ${ }^{14}$ and policy model (organizational structure of state practices in culture) were exported as tools for creating the new socialist reality. By 1940, when the Baltic states were incorporated into the Soviet Union, the Soviet official culture had gone through different phases. The avantgarde and iconoclastic prolet-cult, which with the slogans of class-fight and Cultural Revolution aimed to destroy the traditional culture of tsarist Russia, was replaced by neoclassicism and socialist realism during the mid-1930s - the era of

10 Mertelsmann, O. Everyday Life in Stalinist Estonia. (Tartu Historical Studies, 2.) Peter Lang Internationaler Verlag der Wissenschaften, 2012; see also Zubkova, J. Problematic zone: peculiarities of sovietization in the Baltic States during the post-war period in 1944-1952. - In: Tannberg, T. (ed.). Soviet Estonia 1944-1953: Mechanisms and Consequences of Sovietization in Estonia in the Context of Development of Soviet Union and East-Europe. Tartu, 2007.

11 Mertelsmann, O. Everyday Life in Stalinist Estonia, 14-19.

12 Gerlach, C., Werth, N. State violence - violent societies. - In: Beyond Totalitarianism. Stalinism and Nazism Compared. Eds M. Geyer, S. Fitzpatrick. Cambridge University Press, 2009, 133-179.

13 Indoctrination refers to infiltrating (drilling, inculcating, etc.) concepts, attitudes, beliefs and theories into a student's mind by passing her free and critical deliberation. According to Huttunen the opposite of indoctrination, is communicative teaching, which is based on "The Bildung as a human teaching situation" referring to Schäfer and Schaller $(1975,57)$, where students are not treated as passive objects but as active learners. The Communicative teaching is a simulation of democracy and democratic mode of action, Huttunen explains. See more: http://eepat.net/lib/exe/fetch.php?media=habermas_and_the_problem_of_indoctrination.pdf

14 R. Raud defines cultural canon as an outlook on cultural tradition established in the cultural environment by a symbolic authority, a list on texts supporting its development, which is used as the most valuable part of heritage: Raud, R. What is Culture? Introduction into the Theories of Culture. Tallinn University Press, 2013, 430. 
Stalinist rule. Socialist realism became the Stalinist canon of official culture. Soviet state practices and formation of cultural norms and values have been described as cultivating masses in the frame of developing Soviet modernity. Civilizing and cultivating masses was the main purpose of state cultural policies in the majority of European nation-states at that time. Soviet state practices could be seen as a specific type of coercive modernity according to David Hoffmann. ${ }^{15}$

Sheila Fitzpatrick ${ }^{16}$ offers several concepts explaining the modernizing practices of Soviet state, for example: Soviet society as prison or a conscript army, or strict type of school, with the elements of strict discipline within a closed institution with its own strict codes of behaviour, and fear of punishment. On the other hand, as Fitzpatrick ${ }^{17}$ points out, the Soviet state was moving toward the welfare paternalism, where the state acts with the strong sense of the responsibilities of leadership over the dependent population $(1999,226)$. Thus, Fitzpatrick offers also the concepts - state as the soup kitchen or the relief agency, to explain the state's monopoly of distributing goods and services and the paternalistic dominance of the state apparatus as the one of the significant features of the Soviet political system.

In the same period (1918-1940), a characteristically Western modern social structure gained ground in Estonia for two decades of independence. The state practices of culture in the Estonian Republic (1918-1934) were typical to those nation-states of Western liberal democracies, where cultural institutional network originated from the national and cultural emancipation and initiatives of the 19th century civil society. The Estonian engagement with modernity started in the middle of the 19th century with the growing social activism and continued, as Raun (2009) has described, with the emergence of a new generation of Estonian intellectuals and politicians at the beginning of the 20th century. Also the growth of urbanization among Estonians, and the educational and cultural level, prosperity and the standard of living of the population improved. ${ }^{18}$ Cultural policy developments during the years of Estonian independence (1918-1940) could be described

15 Hoffmann, D. L. Stalinist Values. The Cultural Norms of Soviet Modernity [1917-1941]. Cornell University Press, 2003; Hoffmann, D. L. Cultivating the Masses: The Modern Social State in Russia, 1914-1939. Cornell University Press, 2011.

16 Fitzpatrick, S. Everyday Stalinism. Ordinary Life in Extraordinary Times: Soviet Russia in the 1930s.

17 Ibid, 226.

18 T. Raun presents data and statistics: in 1904, Estonians achieved their first major political breakthrough at the Tallinn municipal elections. In 1913, the percentage of ethnic Estonians had increased in Tallinn to $71.6 \%$ and in Tartu to $73.3 \%$, the two largest towns in Estonia and Northern Livland. The movement of young Estonian intellectuals called "Young Estonia" and its principles developed a fundamental aim for cultural nation-building in 1905: "More culture! This is the first condition for the emancipation of ideals and goals. More European culture! Let's be Estonians, but let's also become Europeans!" (Raun, T. The Estonian engagement with modernity: the role of Young-Estonia in the diversification of political and social thought. Tuna [Magazine Past]. Special issue on history of Estonia of National Archives, Tartu-Tallinn, 2009. http://www.digar.ee/arhiiv/en/download_all/76914 
as gradual movement from the free initiatives of civil society ${ }^{19}$ (before 1925) toward systematic and organized state interference. The years 1925-1929 are considered those that stabilized the country, within the establishment of state supported cultural institutions as well as democratic arm's-length principle ${ }^{20}$ was implemented. Estonia lost its young democracy in 1934, when the political-economic turbulence (economic crises and nationalistic ideas) spread in Europe between the world wars. This era brought nationalist ideology, developed by the propaganda office, which was implemented with the support of a nationalist/popular cultural policy. The objective of the state was a homogeneous and strong nation-state. Authoritarian state practices ${ }^{21}$ in cultural policy, with the main aim to enhance the national cultural identity, were implemented and a well-developed network of cultural institutions was established in Estonia, as Kulbok-Lattik $(2008,2012)$ has noted.

From 1940, the Estonian Western modern development was replaced by Soviet state practices. An authoritarian $\operatorname{state}^{22}$ was replaced with the practices of totalitarian state. Discussing the classic concepts, trying to formulate the distinctive feature that differentiates a totalitarian society from other nondemocratic societies, Juan J. Linz ${ }^{23}$, points out two important characteristics of totalitarianism - a monistic center of power and citizen (forced or manipulated) participation in political and social tasks, when active participation is replaced by passive obedience and apathy, society is losing its totalitarian nature and degrading into authoritarianism.

Community houses, which had operated since the second half of the 19th century on the basis of civil society by hosting leisure time and cultural practices of local people, offer a good example of the sovietization process - how the free initiative activities were subjected to the state administration. In the next chapter

19 According to the statistics presented by Uljas (1987), in 1929 there were 1385 societies of culture in Estonia, in 1940 there were 2200 organizations of non-formal education in Estonia, 60,000-70,000 individual members.

20 In 1925, the law of Cultural Endowment (Kultuurkapital) was completed and passed: KulbokLattik, E. Eesti kultuuripoliitika ajaloolisest periodiseerimisest [On the historical periodization of Estonian cultural policy]. - Acta Historica Tallinnensia, 2008, 12, 120-144.

21 Authoritarianism is the principle of submission to authority, as opposed to individual freedom of thought and action. In government, authoritarianism denotes any political system that concentrates power in the hands of a leader or a small elite that is not constitutionally responsible to the body of the people. Authoritarian leaders often exercise power arbitrarily and without regard to the existing bodies of law, and they usually cannot be replaced by citizens choosing freely among various candidates in elections. The freedom to create opposition political parties or other alternative political groupings with which to compete for power with the ruling group is either limited or non-existent in authoritarian regimes. http://www.britannica.com/ EBchecked/topic/44640/authoritarianism

22 Authoritarianism stands in fundamental contrast to democracy. It also differs from totalitarianism, however, since authoritarian governments usually have no highly developed guiding ideology, tolerate some pluralism in social organization, lack the power to mobilize the entire population in pursuit of national goals, and exercise that power within relatively predictable limits. http://www.britannica.com/EBchecked/topic/44640/authoritarianism

23 Linz, J. J. Totalitarian and Authoritarian Regimes. Lynne Rienner Publisher, Colorado, 2000, 70. 
the formation of the Soviet cultural canon and cultural policy model will be briefly examined by concentrating selectively on the aspects which influenced the cultural practices of folk culture and amateur art in the Soviet Union.

\section{Formation of the Soviet cultural canon}

Immediately after the Soviets grasped power in 1940 in Estonia (and in the other Baltic states) constantly repeated slogans on posters appeared in the press and public places, such as "Soviet Culture is Nationalist in Form and Socialist in Content", "Art Belongs to the People", "Friendship of Soviet Brotherly Nations", "Socialist Realism", etc. These slogans are the key to understanding the Soviet cultural canon and the ideology behind it. Cultural canon was needed to create a system for indoctrination and for re-education of people, it was a tool for political agitation and propaganda.

The term "propaganda" is closely connected with the term "agitation" when speaking about the Soviet practices. According to Lasswell ${ }^{24}$ these two terms were first used by the Marxist Georgy Plekhanov, who defined "agitation" as the use of slogans, parables, and half-truths to exploit the grievances of the uneducated and the unreasonable. Since he regarded both strategies as absolutely essential to political victory, he twinned them in the term agitprop, which was later elaborated upon by Lenin in a pamphlet What Is to Be Done? (1902). In the pamphlet Lenin defined "propaganda" as the reasoned use of historical and scientific arguments to indoctrinate the educated and enlightened (the attentive and informed public, in the language of today's social sciences).

An examination of how the Soviet cultural canon was formed reveals the aims, features and model of Soviet cultural policy, as the formation of the cultural canon and the Soviet cultural policy was situational, as Zubkova (2007) has mentioned. It depended on tasks which were set up in order to solve various structural problems of Soviet Russia that the party leaders were faced with illiteracy, general backwardness of Russia, the restructuring of the economy, etc., which reveals the highly instrumental use of culture in the Soviet cultural policy.

\section{Cultural Revolution and acculturating the masses}

Lenin considered the Cultural Revolution to be the main aim for party leaders:

The main aim of the Cultural Revolution was [...] to cultivate a new human being characterized by a harmonious combination of spiritual richness, moral cleanliness and physical perfection (V. I. Lenin, speaking about the Cultural Revolution, cited in Hoffmann $(2003,150)$ ).

However, an enormous gulf loomed between the utopian visions of the Party leaders and social reality, as Hoffmann $(2003,15)$ notes, after the Revolution and Civil War, Russia was an undeveloped, agrarian country with an overwhelmingly

24 Smith, B. L., Lasswell, H. D., Ralph, D. C. Propaganda, Communication, and Public Opinion: A Comprehensive Reference Guide, vii, 435. 
peasant population. Rates of illiteracy, poverty, disease and infant mortality remained very high. Acculturating the masses was one of the central tasks of the Soviet authorities during the first Five Year Plan (1928-1932) period. Fighting illiteracy, building up social and health care systems can be seen as part of a revolutionary attempt to achieve a rationalized and modernized society (ibid.).

Another aspect of the Cultural Revolution was its use in class struggle and freeing society from the "illnesses of capitalism" and the heritage of bourgeois culture, as Hoffmann ${ }^{25}$ explains it. Thus, the conception of culture during the first decade of the Soviet rule, the first Five Year Plan period (1928-1932) - Proletkult, was futuristic, avant-garde, and iconoclastic. Norms and values (culture, religion) of the previous bourgeois society of the tsarist empire were to be re-evaluated by the breaking of all boundaries (including heated discussions between the proponents of sexual liberation and proponents of the family).

\section{Creating Soviet intelligentsia and socialist realism}

The avant-garde culture was no longer needed to destroy bourgeois culture after capitalist remnants had been eliminated (or deported), agriculture had been collectivized, and a planned economy established, as there was no further economic basis for exploitation and no bourgeois mentality. A new and loyal intelligentsia had been created, as Stalin stated in November 1936:

Our Soviet intelligentsia is a completely new intelligentsia, connected by its roots to the working class and peasantry. It is now a fully-fledged member of Soviet society; together with workers and peasants, as one team, it builds the new classless socialist society. ${ }^{26}$

Once socialism had been achieved (Soviet leaders believed they were achieving socialism already at the beginning of the 1930s), the new purpose of Soviet culture was the perpetuation and legitimation of power. The only officially acceptable form in art and literature after 1932 was socialist realism together with monumental architecture that legitimated the existing order. As Stalin stated in 1932:

The artist ought to show life truthfully. And if he shows it truthfully, he cannot fail to show it moving towards socialism. This is and will be socialist realism. ${ }^{27}$

Socialist realism was a "realist" depiction of how life was supposed to be - an attempt by the Soviet cultural establishment to construct a reality that did not actually exist. Boris Groys ${ }^{28}$ has argued that the avant-garde and socialist realism shared several traits: the desire to transform rather than merely represent life, the belief in a totalistic, all-encompassing artistic vision and contempt for commercialized culture as part of an overall aesthetic-political project - an attempt to organize society and everyday life according to aesthetic sensibilities and political principles.

25 As Vladimir Mayakovsky had declared after the revolution, "We are shooting the old generals! Why not Pushkin?", cited in Hoffmann, D. L. Stalinist Values, 150.

26 Hoffmann, D. L. Stalinist Values, 152

27 Ibid., 160-161.

28 Groys, B. Stalin - stiil [Stalin-style]. - Akadeemia, 1998, 2, 427. 
"Art Belongs to the People!"

According to official rhetoric, the revolution did away with the exploitation and suppression of workers. Factories, land, railways, and banks now belonged to the people. Making use of everything that was more worthy and better than the culture of the past, by critically selecting from the cultural heritage, the Soviet people were to begin building a new, higher kind of socialist culture, led by the Communist Party. As expressed by Kalinin in 1938:

The Soviet system released the creative powers in people by making culture their own. A dream of the best of science, arts and literature came true: people showed due appreciation of and lifted high their cultural heritage, making it part of the new socialist culture (cited in Medvedjev and Hlõstov 1954, 10). ${ }^{29}$

Party leaders selectively incorporated past cultural heroes into the official cultural canon. Hoffmann $(2003,163)$ explains that selective rediscovery and incorporation of Russian classics and pre-revolutionary leading figures of the $\operatorname{arts}^{30}$ into the canon of Soviet culture fulfilled both the (pre-revolutionary) elite's long-standing dream of bringing Russian high culture to the masses and the Soviet goal of creating a common culture to be shared by all members of the population. In 1939, in his speech fixing targets for the gradual transition from socialism to communism, Stalin in a speech said:

We want all the workers and all the farmers to become cultural and educated, and we will make it happen in time (cited in Medvedjev and Hlõstov 1954, 14).

Stalinist culture and cultural policy entailed a wide range of norms and practices intended to transform people's behaviour and create a new social order: the Soviet society. Hoffmann (2003) claims that the Stalinist use of traditional institutions and culture for modern mobilization purposes reflected the general demands for mass politics in Europe after World War I. Stalinist culture was to become as a particular Soviet version or incarnation of the modern mass culture.

Folklore culture - the pluralistic unity of the USSR, "Friendship of Peoples"

In the 1930s, the official Soviet cultural policy emphasized folklore. As Hoffmann (2003, 166-169) describes it, at the First Congress of Soviet Writers in 1934, Gorky championed folklore as

"a genuine expression of people's optimism and aspirations" and suggested that "we need to share our knowledge of the past. It is important for all union republics that a Belorussian knows what a Georgian or Turk is like, [...]". ${ }^{31}$

${ }^{29}$ Medvedjev, A., Hlõstov, F. Külanõukogude kultuurharidustöö [Cultural Educational Work of Local Administrations in the Villages]. Eesti Riiklik Kirjastus, Tallinn, 1954, 10.

30 Pushkin, Tolstoy, and others were enshrined in the Soviet literary canon, in the music of Glinka and other classical composers of the pre-revolutionary era, particularly the "Russian Five" (Balakirev, Cui, Mussorgsky, Borodin, Rimsky-Korsakov) - all famous for their efforts to compose Russian classical music. Also certain political and military leaders from the tsarist past were rehabilitated (Yaroslav the Wise, Ivan the Great, Peter the Great, etc.): Hoffmann, D. L. Stalinist Values, 163.

31 Hoffmann, D. L. Stalinist Values, 166-169. 
This statement marked the beginning of an official campaign to promote folklore. It was connected to another important thesis of the Soviet national and cultural policy "Friendship of Peoples" - which required that all Soviet nationalities be deeply moved by the art of other Soviet nationalities and develop their folklore culture as a representation of the Soviet pluralistic unity. As Slezkine $(1994,447)$ explains it:

This resulted not only in frenzied translation activity but also in histories of the USSR that were supposed to include all the Soviet peoples, radio shows that introduced Soviet listeners to 'Georgian polyphony and Belorussian folk songs', tours by hundreds of "song and dance ensembles", decades of Azerbaijani art in Ukraine, evenings of Armenian poetry in Moscow, exhibits of Turkmen carpets in Kazan, and festivals of national choirs, athletes and Young Pioneers all over the country. From the mid-1930s through the 1980s, this activity was one of the most visible aspects of official Soviet culture. ${ }^{32}$

The government sponsored village expeditions to gather folkloric materials, folk singing competitions, and festivals of national art featuring works produced by various Soviet nationalities. The government established the N. Krupskaya AllUnion House of Folk Art in Moscow, as well as institutes of national culture all over the country. ${ }^{33}$ Folk culture was used by party leaders to promote controlled and artificial representation of Soviet forms of national cultures. An example of political representation of Estonian folklore, see poster 1 from 1947:

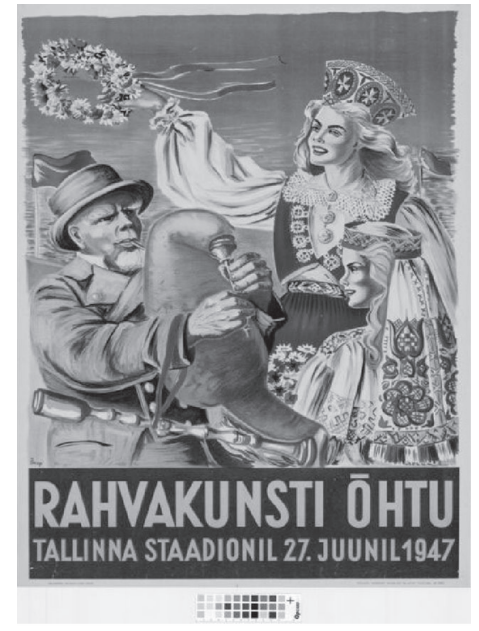

Poster 1. Evening of Folklore Art in Tallinn 1947. Estonian History Museum, Collection of Posters (F158-1-36)

32 Slezkine, Y. The USSR as a communal apartment, or how a socialist state promoted ethnic particularism. - Slavic Review, 1994, 53, 2, 447.

3 Oinas, F. J. The political uses and themes of folklore in the Soviet Union. - In: Folklore, Nationalism, and Politics. Columbus, 1972, 77-78, cited via Hoffmann, D. L. Stalinist Values, 166-169; see also Shay, A. Choreographic Politics: State Folk Dance Companies, Representation and Power. Wesleyan University Press, 2002. 


\section{Russification and nationalism as the ideological basis for Soviet cultural policy}

As a centralized state, the Soviet Union stressed Russian language and Russian culture - official propaganda referred to Russians as the "elder brother" of other nationalities or as "first among equals". Russification was one aspect of the Soviet national and cultural policy. However, the Soviet nationalities policy was based on "national diversity",34, which was a paradoxical prerequisite for "ultimate unity" (within Soviet Socialism)

As Slezkine $(1994,418)$ explains it, Lenin's socialists needed native languages, native subjects and teachers ("even for a single Georgian child") in order to "polemicize with 'their own' bourgeoisie, to spread anticlerical and antibourgeois ideas among peasantry and burghers" and to "banish the virus of bourgeois nationalism from their proletarian disciples and their own minds". Mertelsmann $(2012,12)$ points out that the Soviet nationalities policy, based on the concept of korenizatsiia ("taking root"), to build up and secure the central power the Soviet system needed the help of national cadres. The basic concepts for national and cultural policies were worked out by Lenin and developed by Stalin. The Soviet concept of "national diversity" and "ultimate unity of nations" under the red flag and leadership of Stalin, has been visualized on poster 2:

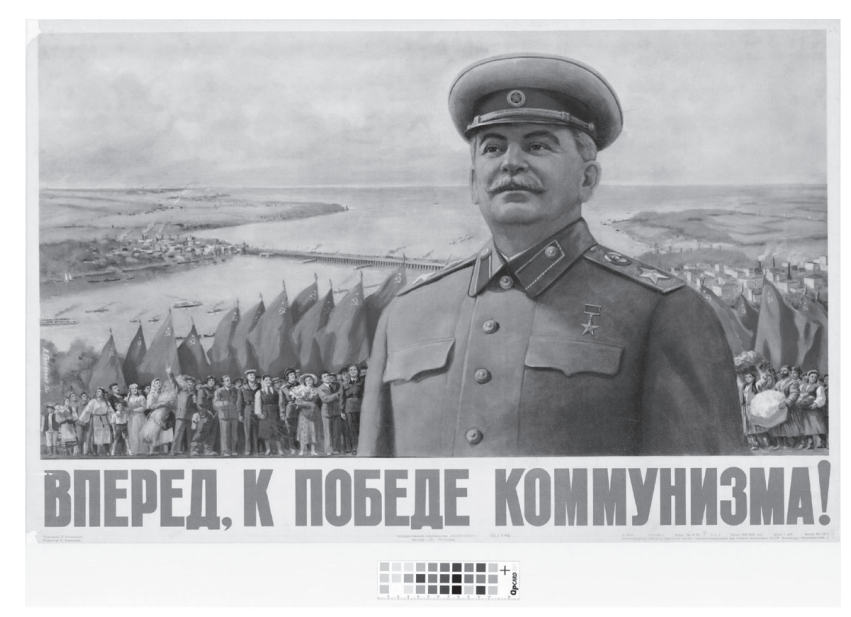

Poster 2. Expression of "national diversity" and "ultimate unity". Estonian History Museum, Collection of Posters (F158-1-23).

34 See also Warshovsky Lapidus, G. Ethnonationalism and political stability: the soviet case. World Politics, 1984, 36, 4, 555-580. 
In 1948, closely resembling his earlier statement on national rights, Stalin said:

Every nation, whether large or small, has its own specific qualities and its own peculiarities, which are unique to it and which contribute to what each nation gives to the common treasury of world culture, adding to it and enriching it. In this sense all nations, both small and large, are in the same position and each nation is equal to any other nation. ${ }^{35}$

According to Lenin, national culture was a reality, it was about language and a few "domestic arrangements": nationality was a "form". National form was acceptable because there was no such thing as national content, as Slezkine $(1994,423)$ notes. The content which filled the national form was socialism. This basic principle for Soviet cultural policy - as set by Lenin and Stalin - was expressed with the main slogan: "Soviet Culture is Nationalist in Form and Socialist in Content", the concept is visualized on poster 3.

\section{State-funded cultural bureaucracy shaping cultural norms and canon}

A specific feature of Soviet cultural policy was its highly bureaucratic nature. As all cultural organizations were state funded, they were also guided and controlled

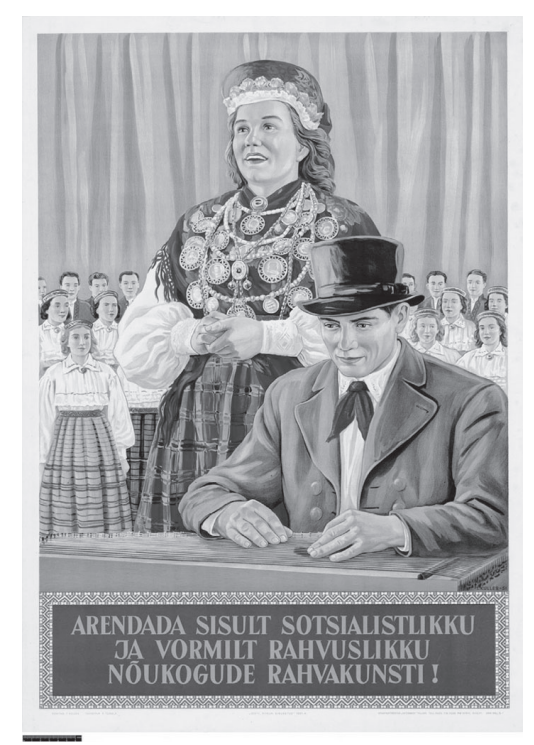

Poster 3. "To Develop Soviet Folklore: Nationalist in Form and Socialist in Content!" Estonian History Museum, Collection of Posters (F158-1-7).

35 Stalin, J. Sochineniya, 3(XVI), 100: cited in Slezkine, Y. The USSR as a communal apartment, 449 . 
by the bureaucracy of state institutions. ${ }^{36}$ However, as Hoffmann notes $(2003,5)$, the party leaders, who retained absolute power in the system, could not dictate the contents of every single propaganda film, hygiene-promoting poster and school textbook produced in the Soviet Union. Instead, they set up a network of institutions and a control mechanism to oversee cultural production and the promulgation of official norms and values.

In cultural policy research, such a dominant role of the state has been described in the Hillmann-Chartrand and McCaughey's theoretical framework as the "engineer state" model (1989). The engineer state acts as the owner of all means of artistic production, supports only the art that meets political standards of excellence. Funding decisions are made by political commissars. Artistic activity (both professional and amateur) is organized into "creative unions" (or methodically-guiding administrative bodies) so as to monitor new works and ensure conformity with the aesthetic principles of the Communist Party. ${ }^{37}$

To summarize, the aims of the Soviet cultural policy were to control and acculturate the masses, to set a common cultural canon and norms to reform and restructure society, with the final aim of constructing a monolithic society and a new type of human being: the Soviet Person. The Soviet cultural policy was characterized by the following features: the cultural policy was hierarchical in essence, promoting high culture and Russian culture for the arts, yet with a strong inclination to support folklore which had become used as the politicized representation of Soviet pluralistic unity. The cultural policy model of the Soviet Union in the mid-1930s-1990s period was carried out according to the engineer state model which was exported and implemented all over the occupied territories of the Soviet Union.

The biggest change in the Estonian society was mental change, related to the suppression of bottom-up free initiative of people, which was not tolerated by state in any spheres of life. The Soviet system with the allocative function of the state, created dependents, as Fitzpatrick ${ }^{38}$ explains, referring to Janos Kornai ${ }^{39}$ who has pointed out that, in Soviet-type systems the population is under the "paternalistic tutelage" and care of the party and state. "All other strata, groups, or individuals in society are children, wards whose minds must be made up for them by their adult guardians." A citizen's natural posture toward a state that

36 The coercive mechanisms of institutionalized structures and practices as the impact of Soviet institutionalization on Estonian cultural policy can be analysed referring to the theoretical concepts of institutional isomorphism. See DiMaggio, P., Powell, W. The iron cage revisited: institutional isomorphism and collective rationality in organizational fields. - American Sociological Review, 1983, 48, 2, 147-160.

37 Hillmann-Chartrand, H., McCaughey, C. The arm's length principle and the arts, 7-8.

38 Ibid., 225.

39 Kornai, J. Economics of shortage. - In: Contribution to Economic Analysis \#131, 2 vols. Amsterdam, 1980, 315, cited in Fitzpatrick, S. Everyday Stalinism. Ordinary Life in Extraordinary Times: Soviet Russia in the $1930 \mathrm{~s}$ 
controls the distribution of goods and benefits is one of supplication, not resistance. As Ray $(2007,512)$ explains it, "This was inevitable in order to repress and hold back one of the most dangerous enemies of the Soviet totalitarian regime civil society - with its liberal market values and community involvement." 40

Below, I try to demonstrate the upheaval related to the sovietization of the cultural practices of folk culture, amateur art of the Estonian population.

\section{THE EXPORTING OF SOVIET CULTURAL POLICY INTO ESTONIAN COMMUNITY HOUSES}

When the Soviet Union seized power in Estonia in 1940, Leninist principles and well-tried scenarios, which the Soviet authorities had used for the purpose of the Cultural Revolution in the Soviet Union, were immediately applied in the reorganization of cultural life.

\section{Banning manifestations of civil society and free initiatives}

For the Estonian societies running the community houses, and other free initiative organizations, everything changed on August 23, 1940, when the Act of Nationalization of Private Companies was promulgated by the Council of the People's Commissars. ${ }^{41}$ This dissolved societies, non-governmental organizations (i.e. museums, libraries, theatres, community houses, cinemas), foundations and private companies. The assets, collections, buildings and inventory of the societies and companies, now without owners, were taken over by the commissaries, were nationalized and handed over to the People's Commissariat for Education of the ESSR. On the basis of acquired material basis, a state network of cultural institutions - community houses (as well as theatres, libraries, cinemas, museums) was created. ${ }^{42}$

On the basis of the regulation of the Council of People's Commissars of the ESSR, adopted on October 9, community houses were turned into centers for political education. The guidelines, ${ }^{43}$ issued a few days later, instructed that the network of community houses was to be set up, and it was to be approved by the People's Commissariat for Education in towns and counties. The new mission of community houses covered the following fields:

40 Ray, L. Civil society. - In: Ritzer, G. (ed.). The Blackwell Encyclopedia of Sociology. Blackwell Publishing, Malden, 2007, 512-513.

41 Riigi Teataja (RT) 1940, 109, 1105.

42 Eesti NSV kultuuriasutuste ajaloo teatmik, I osa [Reference Book of the History of Estonian Cultural Institutions, I part]. Ed. E. Taal. Central State Archives of Estonian SSR, Tallinn, 1982, 4-14 (hereinafter: Reference Book).

43 The Commissariat for Education of the ESSR issued guidelines for community houses on October 15, 1940. Reference Book, 1982, 4-5. 
Political education, agricultural, industrial and propaganda about the country's defensive capabilities, libraries, artistic expression of people, organization of work with children and youth, and many other spheres. ${ }^{44}$

Aleksander Kurvits' account offers a personal perspective on this process. ${ }^{45}$ In 1940, the Ministry of Education issued a compendium compiled by Kurvits A Systematic Guide to Acts, Regulations, Circular Letters and Guidelines on Estonian National Education and Culture. ${ }^{46}$ The publication contains all the acts and regulations, circular letters and guidelines of the Ministry of Education issued in the Republic of Estonia in the period 1918-1940 on the management of national education, activities of educational organizations, qualifications, youth work, libraries, community houses, science, art, literature, heritage protection, and the education and career of academicians, along with respective explanations.

Several months later, in 1941, Kurvits, had to announce a completely new view on free education and culture in the first issue of the Bulletins of the People's Commissariat, which replaced the Bulletin of the Ministry of Education. ${ }^{47}$ In the regulation, specific instructions - proceeding from the N. Krupskaya All-Union House of Folk Art in Moscow - on how to celebrate Lenin's death anniversary in community houses are provided:

It is necessary to make proper arrangements for the memorial day in community houses, clubs, the Red Corners, libraries, etc. early enough and begin preparation and implementation immediately:

1) to arrange a festive memorial meeting in every community house; 2) to arrange various working meetings in different study groups in order to learn about the life and work of V. I. Lenin and the events of the Bloody Sunday; 3) to arrange, also before and after January 22, at an available opportunity, public lectures on V. I. Lenin and January (9) 22, 1905 events in St. Petersburg; 4) to make respective presentations - speeches, declamations, and other - part of various public memorial day meetings and party programs; 5) to publish special issues of pinboard news in community houses and public libraries etc. ${ }^{48}$

This is followed by detailed and elaborate guidelines on how Lenin's memorial day was to be celebrated in community houses and public libraries, what the program must look like, which music and declamations are to be selected, how the Red Corners in community houses are to be decorated, see below (Photo 1).

44 Law: ENSV RKN määrus nr. 260 9. oktoobrist 1940. a. ENSV ORKA f R-1, n 1, s 37, 1457 jj. Reference Book, 1982, 4-14.

45 Kurvits, Aleksander (1896-1958) state official of the Ministry of Education during 1921-1940, who contributed to the development of Estonian free education and establishment of the network of community houses. See Kurvits, A. (ed.). Eesti rahvaharidus ja kultuuriala korraldus [Administration of Estonian Free Education and Culture]. Haridusministeeriumi väljaanne, Tallinn, 1938.

46 Kurvits, A. (ed.). Eesti rahvahariduse ja kultuuriala seaduste, määruste, ringkirjade ja juhendite süstemaatiline üldjuht [Systematic Guide to Acts, Regulations, Circular Letters and Guidelines on Estonian National Education and Culture]. Haridusministeeriumi väljaanne, Tallinn, 1940.

47 Kurvits, A. (ed.). Hariduse Rahvakomissariaadi Teataja. Ametlik Ajakiri [Bulletin of the People's Commissariat, the Replacement of the Bulletin of the Ministry of Education]. Tallinn, Jan, 6. 1941.

48 Kurvits, A. (ed.). Hariduse Rahvakomissariaadi Teataja. Ametlik Ajakiri [Bulletin of the People's Commissariat of January 6 (the Replacement of the Bulletin of the Ministry of Education)]. 1941. Author's translation. 


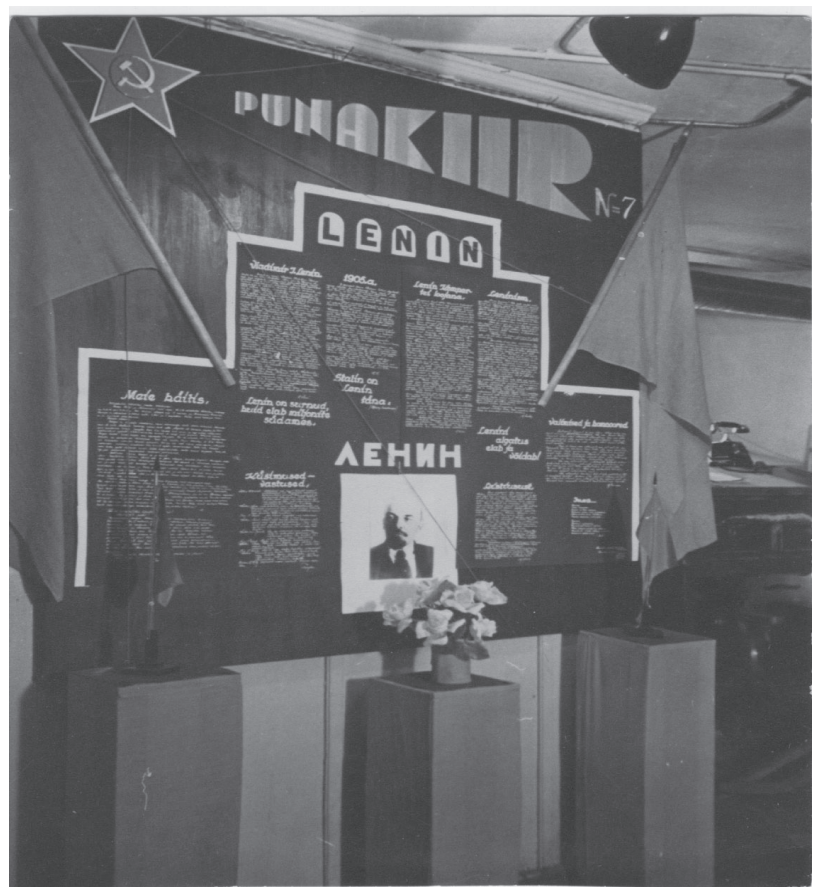

Photo 1. Wallboard "Red Ray" 1941 (Seinaleht "Punakiir") to celebrate Lenin's death anniversary in 1941. Estonian History Museum (AM 1480/R F 2569).

How was the situation perceived by people from community organizations, who had up until August 1940 operated on free citizen initiatives, upon their reading of the new rhetoric and guidelines? Per Wiselgrad $(1942,105)$ has described that many people perceived the hypocritical rhetoric of the new regime as mental oppression. The constitution solemnly promised freedom of the press, speech, association and personal security; in reality none of it was true:

Newspapers were day after day filled with detailed announcements about silly and vacuous meetings and of the decisions made, public calls, resolutions, mottos and watchwords thereof. Salutes to comrade Stalin and other party bosses in newspapers were permanent. Also biographies of Stalin and Lenin were repeated over and over and their portraits were displayed.

The new regime not only censors matters dealing with actual politics but interferes with the free time of people (e.g. workers were made to listen politicians lecture about Marxism and Leninism four times a week, with participation in meetings and demonstrations carefully documented). ${ }^{49}$

49 Wiselgrad, P. Fran Hammaren till Hakkorset. Estland 1939-1941. Ide och Form Förlag, Stockholm, 1942, 105 
Aarelaid $(2006,175)$ has described how the abrupt reversal in cultural norms and values caused traumatic syndrome and double-mindedness in people. ${ }^{50}$ People were psychologically not ready to lose their memories of the independent nation state.

As described above, from the very first moments of the new regime, community houses, in addition to the direct administrative subordination, had to follow methodical guidelines, which were labelled as help and sharing of experience. These guidelines, which were tied up and subordinated to the Five Year Plan cycle's directions and plans of the Soviet Communist Party, were compiled in the Soviet Union central institution, the N. Krupskaya All-Union House of Folk Art in Moscow, and shared by local institutions of Soviet Republics ${ }^{51}-$ in the forges of methodological guidelines and mandatory repertoire.

With the same regulation of October 9, 1940, with which societies and unions were dissolved and their assets nationalized in Estonia, the Centre for Folk Arts was established under the department of political education in the People's Commissariat of the ESSR. The Centre for Folk Arts took over the functions of the Estonian Education Association, the Estonian Singers' Union and the National Estonian Youth Organization of the previous era. All larger choirs, folk dance groups and orchestras which had operated as part of the dissolved societies were now subject to the Centre for Folk Arts, the code of conduct of which was adopted on October 30, 1940..$^{52}$ The mission of the Centre for Folk Arts was "to promote and administer amateur arts". 53

In 1940 and 1941, the legal structure for the sovietization of community houses was set but due to the beginning of World War II, there was no time for a full implementation of the system. Archival dossiers ${ }^{54}$ show that the existing network of community houses was thoroughly studied by the authorities of the People's Commissariat for Education of the ESSR. Extensive reports with precise data on community houses and the people involved (location of the community house,

50 Double-mindedness (the emergence of double standards) is a deep socio-psychological mechanism for the adaption of people living under the unfavourable conditions caused by major historical upheavals. The main function of this mechanism is the self-protection of individual identities in the permanent coercive process of switching over from one ideological system to another (Aarelaid-Tart, A. Cultural Trauma and Life Stories. (Kikimora Publications A., 15.) Gummerus Printing, Vaajakoski, 2006, 192-193.

51 Methodical guidelines from the N. Krupskaya All-Union House of Folk Art in Moscow to Estonian Centre for Folk Art in 1955. Eesti Riigiarhiiv (ERA) [Estonian State Archive]. ERA.R.-28.2.147; Archival Documents of the People's Commissariat for Education of the ESSR (1940-1941). ERA.R.-14.1.926; ERA.R.-14.1.914; ERA.R.-14.1.556; Archival Documents of the Committee for Organizations of Cultural Education (1945-1953). ERA.R.-1570.1.57; ERA.R.-1570.1.247; ERA.R.-1570.1.179; ERA.R.-1570.1.152; ERA.R.-1570.1.192; ERA.R.1570.1.262; ERA.R.-1570.1.339; ERA.R.-1570.1.434; ERA.R.-1570.1.131; Archival Documents of the Folk Art House (1940-1959). ERA.R.-28.2.87; ERA.R.-28.2.147; ERA.R.-28.2.151; ERA.R.-28.2.2.3; Archival Documents of the Folk Art House (1966, 1967, 1973). ERA.R.28.2.318; ERA.R.-28.2.338; ERA.R.-28.2.314; ERA.R.-28.2.369; ERA.R.-28.2.487.

52 Reference Book, I, 84-85.

53 ENSV Teataja 1940, 37, 442.

54 Archival documents of the People's Commissariat for Education of the ESSR (1940-1941). ERA.R.-14.1.926; ERA.R.-14.1.914; ERA.R.-14.1.556. 
year of construction, condition of buildings, the number and type of amateur hobby groups, the number of people participating in the activities, the social status, as well as educational level of the people leading the community houses and amateur art activities) about each Estonian county were compiled (ibid.).

By the autumn of 1941, Estonia had been taken over by German troops. During the German occupation, the former state of cultural affairs was re-established and assets, buildings and collections were returned to societies. An active cultural life in Estonia continued largely as it had during independence. However, the conditions of the occupation cannot be called free: the German occupying troops persecuted and executed Jews and communists or suspected communists, including writers, artists and socially active people.

During the years of the loss of independent statehood a large part of the cultural and art elite left and a strong nationalist feeling, which had existed were dispersed into the different worlds of the East and the West. The biggest losses of creative people and artists came with the emigration to Germany (1939-1941), the 1941 June deportation and the forced conscription to the Soviet army. ${ }^{55}$ From 1944, when the Red Army took over the Estonian territory once again, the situation was again reversed and sovietization continued. After World War II, the Soviet legal structure for administering amateur arts was secured; nonetheless several restructurings ${ }^{56}$ took place until in 1959 the administrative institution for amateur arts was named the Folk Art House of the ESSR, which was subject to the Ministry of Culture.

\section{Sovietization of community houses after World War II}

In May 1945, the Council of Peoples' Commissars of the ESSR adopted new rules for the administration of community houses. ${ }^{57}$ The regulation was accompanied in the same year by instructions and mandatory standard statutes for community houses, which, in Chapter 5, laid down the following: the mission of community houses, the content and form of work, types of community house, administration and organization of work, rules for the management and dissolution of the community house. According to the document, community houses were categorized according to duties into the following types: town, central, county, central parish and local parish community houses. The network of community houses was drawn

55 Karjahärm and Luts (2005) and Kuuli (2007) describe the preparatory steps in re-education the intelligentsia and creating the new cultural elite by the Soviet authorities during the war. See Karjahärm, T., Luts, H.-M. Kultuurigenotsiid Eestis. Kunstnikud ja muusikud 1940-1953 [Cultural Genocide in Estonia. Artists and Musicians from 1940-1953]. Argo, Tallinn, 2005; Kuuli, O. Stalini aja võimukaader ja kultuurijuhid Eesti NSV-s (1940-1954) [Stalin-era Cadres in Power and Cultural Administrators in the Estonian SSR (1940-1954)]. Tallinn, 2007.

56 Referencwe Book, I; Kuuli, O. Stalini aja võimukaader ja kultuurijuhid Eesti NSV-s (19401954).

57 Borkman, A. (ed.). Eesti ENSV RKN määruse juurde nr. 464 25. maist 1945. Rahvamajade töö korraldamise eeskirjad. Eesti NSV Asjadevalitseja Riiklik Kirjastus "Poliitiline kirjandus", trükikoda "Kommunist", Tallinn, 1945. 
up by local party organizations in Estonian towns and counties and approved by the People's Commissariat for Education of the ESSR. The new mission of community houses was stated to be:

the cultivation of active and informed builders of the socialist society by politically educating people in the soviet spirit, organizing mass political, culturally and generally educating events and providing quality recreation and entertainment. ${ }^{58}$

Achieving the objectives according to the mission, a community house:

(a) carries out mass agitation in order to explain the decisions of the All-Union Communist Party (Bolsheviks) and the Soviet Government; helps party and council bodies in organizing masses of workers and officials for the execution of those decisions; (b) helps workers in learning the Marxist-Leninist theory; (c) teaches socialist regard to work and public property, explains and implements measures for increasing productivity, especially in agriculture, by popularizing agricultural engineering; (d) carries out work in masses during the elections of the Councils of Workers' Representatives, public organizations, lay judges, etc., and arranges reporting events for workers' representatives and other publicly elected officials; (e) arranges the explaining of domestic and external policy events of the Soviet Union; (f) organizes mass propagation of military knowledge and helps in preparing the population for the protection of the immunity of the Soviet Union; ( $g$ ) helps to raise the cultural-technical level of the population and popularizes scientific, technical, literary and artistic achievements; (h) organizes cultural recreation and entertainment (ibid.).

As can be seen from the above, the work, activities and functions of community houses were explicitly outlined by the authorities. It was a fully politicized agenda with the central task of ideological work for creating the Soviet person and cultivating the masses in accordance with the ideas of building socialist society, that is, the new reality of Soviet Modernity. In addition, with duties provided in the statutes, an institutional system of control and hierarchy was put into effect, with community houses of larger towns or county centers being in charge of coordinating the methodical (ideological) work, as well as central methodical and administrative bodies.

The legal structure for the sovietization of community houses was set and prepared for the full implementation of the system straight after the war in 1945 . Comparing the mission and objectives given to the community houses by the state during the first Estonian Republic (Law adopted in 1931, see above) and Soviet Estonia (rules adopted in 1945), we can see remarkable differences in the roles given to the community houses by the state: from the "centers for cultural and free educational activities" (1931), community houses were turned into "centers for the cultivation of active and informed builders of the socialist society by politically educating people in the soviet spirit" (1945).

The examination of the rules and guidelines above shows that the importation of Soviet coercive state practices and the cultural policy model was systematic, starting with an abrupt legal reconstruction of society, and proceeding with the building up of a top-down governed network of institutions (including trained personnel and professionals).

\footnotetext{
58 Reference Book, I, 84-85.
} 


\section{NEW ROLES OF COMMUNITY HOUSES AS CENTERS FOR POLITICAL EDUCATION, SOVIET GUIDELINES}

As centers for political education, community houses were intended to contribute actively in the re-education process of the Estonian population. To understand how the process was conducted practically, I analyse some of the new tasks of community houses, which were mediated through methodical guidelines. As mentioned above, the guidelines were tied up and subordinated to the Five Year Plans' directions, plans, and decisions adopted at party congresses and sittings. "The Restoration and Development of the National Economy, 1946-50" was set as the main goal for the first postwar Five Year Plan of the USSR, adopted in March 1946 sitting of the Supreme Soviet of the USSR. All-union objectives set by the communist party were mandatory as ultimate goals for all Soviet nations.

However, in every republic, the implementation of all-union goals depended on local party leaders, cultural administrators, professionals and historical peculiarities. In Estonia, as a new republic of the Soviet Union, in addition to the restoration of the national economy, the most important goals of the Estonian Communist Party (ECP) during 1945-1948 were related to the exchange of personnel, thus, creating a loyal cadre for carrying out cultural revolution and class fight as Kinkar (1967) has stated. ${ }^{59}$ Kuuli (2007) in his study describes the replacement of the former elite of the independent republic ${ }^{60}$ in the education and cultural system.

Archival dossiers from 1946 and 1948 of the Committee for Organizations of Cultural Education ${ }^{61}$ show that Stalinist coercion, the re-education with the Soviet cultural canon, became the reality for Estonian community houses immediately after World War II, when the activity was based only on controlled and prescribed guidelines. Mandatory guidance materials, thematic brochures and recommended repertoires of methodical guides were compiled in the N. Krupskaya All-Union House of Folk Art in Moscow, the Estonian Ministry of Culture, and its subsidiary, the Central Methodical Cabinet for Cultural Education, later the Folk Art House of the Estonian SSR. ${ }^{62}$ Various booklets were provided in order to support larger all-union economic goals, for teaching hygiene, work education, atheism, moral codes for the builder of communism, etc. (ibid.).

However, it has to be mentioned that ideological pressure was just a part of the matter. Not all the guidelines and activities of the Folk Art House of the

59 Kinkar, F. EK(b)P Keskkomitee pleenumite ja büroo istungite protokollid Eesti NSV-s toimunud kultuurirevolutsiooni uurimise allikana (1944-1948) [On the activities of the Central Committee of the Estonian Communist Party in leading cultural work in the years 1944-1948]. (Töid NLKP ajaloo alalt,V.) Tartu Riiklik Ülikool, 1967, 111-123.

60 Kuuli, O. Stalini aja võimukaader ja kultuurijuhid Eesti NSV-s (1940-1954).

61 Archival documents of the Committee for Organizations of Cultural Education (1946). ERA.R.1570.1.57 and (1948). ERA.R.-1570.1.131.

62 Archival Documents of the Folk Art House (1940-1959). ERA.R.-28.2.87; ERA.R.-28.2.147; Dossiers of the Committee for Organizations of Cultural Education (1945-1953). ERA.R.1570.1.322; ERA.R.-1570.1.434; ERA.R.-1570.1.192; ERA.R.-1570.1.152. 
Estonian SSR should be treated as pure ideology work, especially during the post-Stalinist era. For example, according to Lenin's call, "Communism - Soviet authority together with the electrification of the whole country", an all-union goal was set to build large power plants, hydro- and thermoelectric plants based on local fuels, in order to provide electricity for districts and kolkhozes. In 1953, the guidelines "Program for the Electrotechnical Group in the Community House"63 were published, providing 50 theoretical and 26 practical lessons for Estonian community houses. Practical manual labor skills were important for overcoming the material shortages of the postwar years, the burden of which was eased by programs organized in community houses. For example, the 1957 "Model Program for the Sewing Group" ${ }^{\circ 4}$ :

Manual and machine sewing, program of 160 hours with work taking place from SeptemberMay, 1-2 times a week, 2-3 hours at a time: practice work, making a cotton dress, a blouse, a skirt, a woolen dress, construction of cutting etc. (ibid.).

In order to promote the work of acting groups, in 1958 a study book on declamation art, The Work of a Declamator, based on the technique of psychological realism by Stanislavski, was published. ${ }^{65}$

All in all, the guidelines reveal that despite the changes in the political climate in the Soviet Union after the death of Stalin in 1953, from the second half of 1950s, when repressions were replaced by the Khrushchev Thaw, and the liberal trends of the $1960 \mathrm{~s}$, the official ideological line and rhetoric in the central cultural policy remained the same: expressing the norms of Soviet cultural canon with the aim of cultivating the masses. In 1970, "Thematic evenings" were published, with thematic and artistic suggestions on how to organize leisure activities for the Estonian population, e.g.: "Montage, Programmes for Declamation and Agitation", "My Other Heart", "Lenin - The Flag of All Victories", "Lenin State Leader and Man" ${ }^{66}$ In 1971, a brochure about "Military/Patriotic Education" was released. ${ }^{67}$

In order to demonstrate the process of sovietization of Estonian community houses, I have chosen to include in this article some of those guidelines from among various booklets mediated via Folk Art House of the Estonian SSR to community houses, which clearly demonstrate the use of guidelines for ideological purposes of Soviet propaganda.

63 Kozlov, M. D. Õppekava Elektrotehnika ringile rahvamajas [Programme for the Electrotechnical Group in the Community House]. - In: Eesti NSV Kultuurhariduslike asutuste peavalitsus, kultuurharidustöö metoodiline keskkabinet. Ed. H. Kulbok. Trükikoda "Kommunist", Tallinn, 1953.

64 Õmblemisringi näidisõppekava [Model Program for the Sewing Group]. Kultuurharidustöö metoodiline keskkabinet, trükikoda "Tallinn", 1957.

65 Bender, N. A. Deklamaatori töö [The Work of a Declamator]. Eesti NSV Kultuuriministeeriumi kultuur-hariduslike asutuste valitsus, Eesti NSV Rahvaloomingu ja metoodilise töö keskmaja, trükikoda "Tallinn", 1958.

66 Temaatilised õhtud [Thematical Evenings]. Eesti NSV Rahvaloomingu Maja, trükikoda "Tallinn", 1970.

67 Sõjalis-patriootlik kasvatustöö [Military/Patriotic Education]. Eesti NSV Rahvaloomingu Maja, trükikoda Tallinn, 1971 


\section{Community houses as tools for the sovietization of Estonian rural life}

During the first independent state, the establishment of the network of community houses as significant tools of regional cultural policy was clearly the expression of socio-economic and cultural vitality of Estonian rural regions. The vitality of rural regions based on the successful Land Act (1919), which expropriated almost all of the landed property which had mostly belonged to the Baltic-German nobility, leaving the latter just over 50 ha each. ${ }^{68}$ The Estonian government chose a peasant-based strategy of development (along the lines of Denmark and the Netherlands) where agriculture was the predominant sector of the economy. Modern ideas spread among the educated rural population. Peasantbased development has been described as a success story - due to agricultural societies and state subsidies. Kõll $(1994,12-15,130)$ has pointed out that Estonian peasants were relatively successful agricultural exporters on the world market in the 1930s (especially of meat and dairy products). Estonia was one of the largest food producers per capita in Europe. ${ }^{69}$

With the incorporation of the Baltic states into the USSR in the summer of 1940, the transition from market to Stalinist command economy began. Together with the radically changing principles of economy ${ }^{70}$ the traditional look of Estonian villages had to be changed, as had happened in Russia, in accordance with the vision of Party authorities. In his speech at the AUCP(b) 17th Congress in 1934, Stalin said to characterize old villages:

The old village with a church in the most distinguishable spot, with finer houses of the uriadnik, priest and kulak in the forefront - is disappearing. It is taken over by a new village with its societal and economic buildings, its clubs, radio, cinema, schools, libraries and nurseries, its tractors, combine harvesters, threshing machines and cars. There are no more such notable characters as kulaks/exploiters, usurers/bloodsuckers, traders/profiteers, and patronizing uriadniks (Stalin 1934, cited in Medvedjev and Hlõstov, Cultural Educational Work, 1954, 10). ${ }^{71}$

Noting the rapid increase in cultural level in the Soviet villages, Kalinin wrote in 1937:

Earlier a peasant had a hard time making his way to the heights of human knowledge... Now the village has almost caught up with the town - there is quite a dense network of not only elementary schools but also secondary schools in the villages. Machine powered production itself promotes development of initiative in villages, the courageous steps of the children of peasants in

68 Such a semi-socialist reform was possible mainly because the upper class had hitherto consisted of ethnic Others (Baltic Germans and Russian officials) and this had also prevented further stratification among Estonians. See Annist, A. Otsides kogukonda sotsialismijärgses keskuskülas: arenguantropoloogiline uurimus [Seeking Community in Post-Socialist Central Villages]. Tallinna Ülikooli Kirjastus, 2011, 76-79.

69 Kõll, A. M. Peasants on the World Market: Agricultural Experience of Independent Estonia 1919-1939. Stockholm, 1994, 12-15, 130.

70 Mertelsmann (2012) and Keep (1995) introduce the wider aims of Stalinist agricultural policy, which might be seen as a mode to channel funds from agriculture into the hands of the state to finance industrial investments: Keep, J. L. H. Last of the Empires. A History of the Soviet Union 1945-1991. Oxford University Press, 1995, 244-262.

71 Stalin 1934, cited in Medvedjev and Hlõstov: Cultural Educational Work, 10. 
the fields of science, technology and arts. [...] The peasant has become the small-holding collectivist creating cultural, prosperous life... The peasant has become the real master, creator of his own happiness (Kalinin, 1938 cited in Medvedjev and Hlõstov, Cultural Educational Work, 1954, 10).

However, according to Mertelsmann $(2012,90)$, Estonian people had heard (from soldiers of the Red Army and the German Army, and also from people returning from evacuation to the Soviet Union after the war) about the realities of the collective farm system and about poverty, hunger and devastation in the kolkhozes. Estonian peasant households tried to stay away from kolkhozes.

After the mass deportation of 1949 , the locals who had so far collectively avoided joining the kolkhozes/sovkhozes, were forced to join both by fear and by various tax measures. By January 1, 1950, 80\% of farms were collectivized; one year later the figure was 93\%. While in 1939 there were approximately 140,000 single farms in Estonia, by the end of the Stalinist era there were 934 agricultural and 84 fishing kolkhozes in the country. ${ }^{72}$

Community houses had to assist the authorities in carrying out the collectivization of Estonian agriculture and the reshaping of life in the villages. ${ }^{73}$ Already in November 1944, the Estonian Communist Party was discussing thoroughly the question of "the work of community houses in the village". Kinkar $(1967,123)$ has described the 5th plenary session of the ECP in 1945, where the direction was taken to the fight against bourgeois nationalist tendencies and anti-soviet elements in rural areas. ${ }^{74}$ In 1949, the Committee for Organizations of Cultural Education issued the "Standard Statutes for Kolkhoz Clubs", with Chapter 6 stating the aim of the kolkhoz club, rooms and furnishings, organization of work, funds, auditing of finances, and liquidation:

Organizations of cultural education in the village help party organizations to educate village workers in the communist spirit, develop their culture, mobilize kolkhozniks to meet the plans of the national economy.

The correct deployment of communists and communist youth in the most important sections of work, systematic control and fixing of work plans of clubs, reading rooms, cultural houses, and libraries, organizing the work of political-agro-zootechnical clubs and village lecture rooms, managing the work of the press and radio, massive development of amateur activities in the field of physical culture, sports and arts are focused on increasing the importance of organizations of cultural education in the communist education of workers in the kolkhoz village, etc. ${ }^{75}$

The de-Stalinization and modest liberalization of Soviet society following the 20th Congress of the Communist Party of the Soviet Union in 1956 ended the socalled "severe class struggle period" in Estonia, as Aarelaid-Tart $(2006,169)$

72 Liquidation of the kulaks as a class was carried out according to the Stalinist model, with at least 1,200 families deported in 1947, and in March 1949, 20,700 people were deported to Siberia, with the aim of scaring the Estonian people into submitting to the kolkhoz regime (AarelaidTart, A. Cultural Trauma and Life Stories, 168).

73 See Paavle, I. Sovietization of Local Administration in Estonia 1940-1950. Thesis of Tartu University, 2009. http://dspace.utlib.ee/dspace/bitstream/handle/10062/14206/paavle_indrek.pdf?sequence=1

74 Kinkar, F. EK(b)P Keskkomitee pleenumite ja büroo istungite protokollid Eesti NSV-s toimunud kultuurirevolutsiooni uurimise allikana (1944-1948), 123.

75 Kolhoosiklubi tüüp-põhimäärus [Standard Statutes for Kolkhoz Clubs].Trükikoda "Punane Täht", Tallinn, 1949, 20. 
argues, and created an environment for certain social liberalization. Khrushchev's campaign to increase the role of the agricultural economy and to minimize the difference between rural and urban regions resulted in prospering agriculture in Estonia, a country with a long tradition of peasant farming. ${ }^{76}$

\section{Promoting socialist working competitions}

To promote the planned economy in the relevant Five Year Plan cycles (where demand and supply in production were not necessarily interrelated) and its dwindling productivity, socialist working competitions were used. The following guideline offers an example of how community houses contributed to such Communist Party tasks. A methodical guide of 1958, "A Guide for Club Workers. Evening for Advanced Agricultural Workers in Keila District Cultural House" begins with an assertion:

The aim of workers in the field of cultural education is to assist village workers in carrying out their obligations. In the brochure, an evening of kolkhozniks in Keila district cultural house on the topic of 'We shall catch up with the United States in per capita butter, meat and milk production' is described.

Soviet people have warmly welcomed the party call for catching up with the United States in the per capita production of butter, meat and milk in the coming years. Those working in the field of agriculture understand that the goal set by the party is not easy, but it can be accomplished.

To reach the goal set by the party (to gain on America), the club must become a center where kolkhozniks and sovhozniks can learn and further their education. In order to increase production rapidly and in the shortest period of time, one must rely on science and progressive practices. In his speech at the January plenum of the Central Committee of the CPSU, N. S. Khrushchev called science a compass without which it is impossible to move on. ${ }^{77}$

Heroes of socialist labor were presented with red flags and pennants, one of the rehearsal rooms of the cultural house was made to look like a national farmhouse, selling home brew, blood sausages, legs of pork, and other national dishes; the acting group performed the play Fortune Hunters on the topic of kolkhoz life by E. Vaigur.

The evening's dance was to take place to the music of the brass band and folk music orchestra of the cultural house: Program of the evening:

1. Presentation "Reaching the national goal - catching up with the United States in per capita butter, meat and milk production in the coming years - in district kolkhozes" Presenter Comrade Vooglaid, secretary of the Committee of Keila District of the ECP.

2. Speeches by progressive agricultural workers.

3. Rewarding of progressive agricultural workers.

4. Fortune Hunters, a comedy by E. Vaigur, by the drama group of the cultural house.

5. Dancing to the music of a brass band and folk music orchestra.

76 However, it was not the case everywhere in the Soviet Union. In general, agriculture in the Soviet Union remained inefficient despite enormous inputs of money and manpower, explains Keep, J. L. H. Last of the Empires. A History of the Soviet Union 1945-1991, 119.

77 Abiks klubitöötajale. Põllumajanduse eesrindlaste õhtu Keila rajooni kultuurimajas [A Guide for Club Workers. Evening for Advanced Agricultural Workers in Keila District Cultural House]. Ed. K. Võsa. ENSV Rahvaloomingu ja metoodilise töö keskmaja, trükikoda "Bolševik", Viljandi, 1958. 
The guidelines instruct that thematic evenings should be organized in order to increase the motivation of kolkhoz workers:

Also the performances of amateur agitation brigades have to aid in every way in achieving the competitive goal set by the party. The workers of our clubs are experienced in organizing thematic evenings. Thematic evenings as an influential form of club work must widely be used in helping kolkhozniks achieve the goals set to them.

Guidelines and instructions on how to create agricultural corners in community houses were published. A guideline from 1961, "The Agricultural Corner in a Club", instructs:

Clubs and libraries must tirelessly advocate the communist party policy and decisions, act as centers for disseminating agro-biological sciences and advanced experience. Also of importance is the development of socialist competition between workers, promoting the work experience of advanced workers, and helping colleagues who are lagging behind. In this case, all verbal and visual forms of agitation must be used.

Clubs and libraries must organize lectures, presentations and discussions on the following topics: "Catching up with the US in per capita livestock production in the coming years this is an inseparable part of the main goal of the economy of the USSR" or "The slogan of the party - to catch up with the United States in per capita meat, milk and butter production expresses the tireless care of the CPSU for the wellbeing of people".

Also visual agitation - banners, placards, periodically-issued bulletins, leaflets, flyers, etc. have an important role to play in highlighting the socialist competition and encouraging advanced work results. ${ }^{78}$

An example of how banners of socialist competitions should look, see Fig. 1:
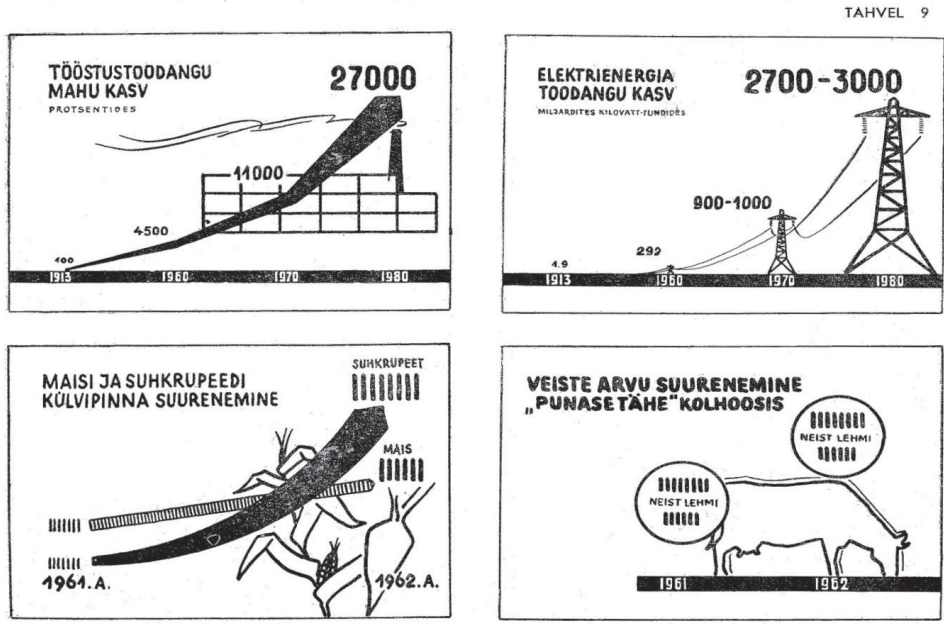

Fig. 1. The Banner in the Agricultural Corner in a Club, 1961.

78 Põllumajandusnurk klubis [Agricultural Corner in a Club]. Eesti NSV Rahvaloomingu Maja klubitöö metoodiline kabinet, trükikoda "Kommunist", Tallinn, 1961. 


\section{Visual agitation}

Visual agitation was meant to be not only in clubs but also in kolkhoz centers, cattle farms and agricultural brigades. A methodical guide of 1962, the "ABC of Visual Agitation. Methodical Guide to Creating Visual Means in Club" states:

Beside verbal and printed propaganda, visual agitation in institutions of cultural education is also important; it is in fact the first measure a club uses in educating its visitors. Visual means helping to introduce the public to the noble ideas of Marxism-Leninism, the goals of the CPSU programme, party and government decisions, scientific and technological achievements, working victories in all spheres of the national economy, the fight for peace, etc. ${ }^{79}$

In order for the visual agitation to work, it must be current, tied to local topics, aesthetically pleasing, and meet certain artistic requirements:

- Banners (permanent banners, temporary banners, their location, composition, choice of materials, implementation)

- Hall of Fame, pinboard news, sample montage, tables with statistics of working victories, framing, composition, etc. (ibid.)

In order to achieve aesthetically impressive results, many examples about how to design a hall of fame, banners, adverts of concert programs, cinema or dancing evenings, etc., were given in the booklet. Examples of the hall of fame and different compositions of banners (their location has to be designated) see Fig. 2.

To improve the skills of people who worked in the community houses, the centralized system of Soviet cultural education was established in Estonia. Cultural workers were trained at innumerable courses and seminars, held on regular basis under the guidance of professionals: visual artists, choir and orchestra conductors,

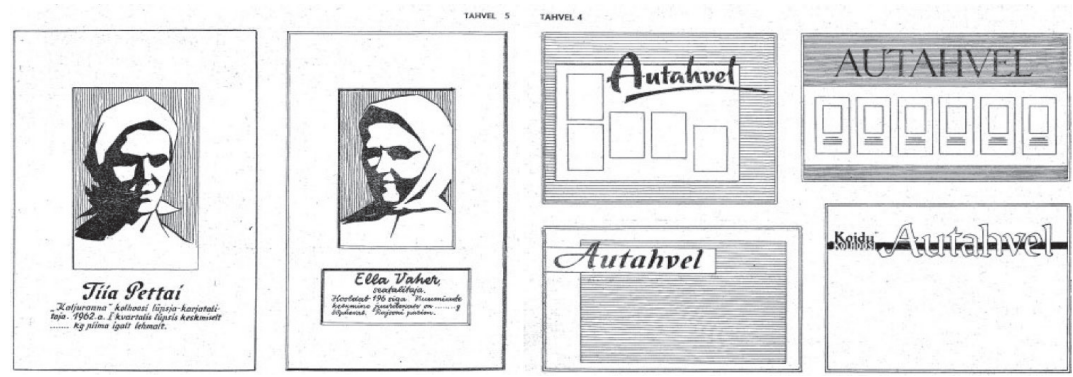

Fig. 2. Compositions of a hall of fame "The ABC of Visual Agitation. Methodical Guide to Creating Visual Means in Club," 1962.

79 Virkus, M., Kivi, A. Näitliku agitatsiooni ABC. Metoodilisi juhendeid näitlike vahendite kujundamiseks klubis [The ABC of Visual Agitation. Methodical Guide to Creating Visual Means in Clubs]. Eesti NSV Rahvaloomingu maja klubitöö metoodika teaduslik kabinet, trükikoda "Pärnutrükk", 1962. 
dancers and choreographers, also library work, theatre and declamation and other activities were taught, which naturally increased the professional quality of cultural workers and thus improved the level of amateur art practices. However, standardization and dissemination of the prevailing canon, as well as ideological training, represented an important part of this type of training course and seminar.

\section{Industrialization and "Friendship of Nations"}

In 1952, active campaigning of the norms of the Soviet cultural canon including russification and friendship of nations was taking place simultaneously with major changes in the Estonian economy. During the early part of the century, the major emphasis had been on textile and food production. By 1950, however, a significant shift towards heavy industry had taken place. The Moscow Administration started to send large numbers of Russian-speaking workers to be employed in these industries in other republics, although the officially declared aim was to remedy the lack of a sufficiently large workforce caused by heavy losses during the war. Forced industrialization was closely connected with a specific political policy, aimed at restricting the role of native Estonians in society, as Aarelaid-Tart $(2006,168)$ pointed out. The share of ethnic Estonians within the population decreased from $94 \%$ in 1945 to $62 \%$ in $1989 .{ }^{80}$

Explanations and re-education of the population was needed for the on-going processes of sovietization, so in 1952, the Central Methodical Cabinet issued the following guidelines: "Demonstrating the Friendship between Estonian and Russian People in the Historical Expositions of Museums". The first paragraph of the document explains:

Studying the historical connections of Estonian and Russian people, the development of friendship between the masses of both nations, and showing the correct treatment of this based on the Marxist-Leninist view on history is a political goal of immense importance. The brotherly friendship of Soviet people grows and strengthens day by day in this monolithic competitive union of communism being built in our country. This friendship must actively be reinforced by the workers of the Soviet ideological front, the first goal of whom is educating people in the spirit of friendship between nations and co-operation. The key to solving this matter lies in the revealing of bourgeois-nationalist tendencies and the scientific invalidation of those tendencies, etc. $^{81}$

Examples on how to enhance the friendship between the brotherly nations of the Soviet Union republics and other socialist countries of the Eastern Bloc are provided in a series of methodical booklets introducing life, cultural and economic achievements made during socialism, e.g., "Introducing Brotherly Republics: Hungary

80 Kasekamp, A. A History of the Baltic States. Palgrave Macmillan, 2010, 155.

81 Eesti ja vene rahva sõpruse näitamine muuseumi ajaloolises ekspositsioonis [Demonstrating the Friendship between Estonian and Russian People in Historical Expositions of Museums]. Kultuurharidustöö metoodilise keskkabineti materjal. Ed. A. Sillaots. 40 eksemplari, paljundatud Loengute Keskbüroo rotaatoril. Tallinn, 1952. 
and the Tajik SSR", ${ }^{82}$ issued in 1965 by the Estonian Central Methodical Cabinet for Cultural Education.

However, the basic ideological orientation of the Soviet cultural policy was set already in the 1940s, thus this kind of slogans and photos had to be displayed on walls before World War II, as can be seen in Photo 2, below.

\section{Mandatory repertoire and censorship}

In Soviet grass-roots-level cultural work, persistent checks, reports, fixed repertoire in music, theatre plays and other amateur arts became an inevitable part of everyday life from the first days of the new regime. The legislative basis for Soviet censorship was the Decree on the Printed Word, adopted on October 27, 1917 by the Council of Peoples' Commissars, and it was in force until 1990. The role of censorship (pre-, post- and permanent censorship) was broad - all artistic creations (literature, music, art, newspapers, TV and radio programs, as well as amateur art practices in community houses) were subject to it. As Veskimägi $(1996,327)$ notes, "not a single printing office accepted any manuscript without the imprimatur of the censor. The Soviet censorship system was duplicated and performed by many authorities - by the central committee of the CP of the republics, the KGB, the Council of Ministers and Glavlit [The USSR Chief Office of Literature and Publishing Affairs ]. ${ }^{83}$

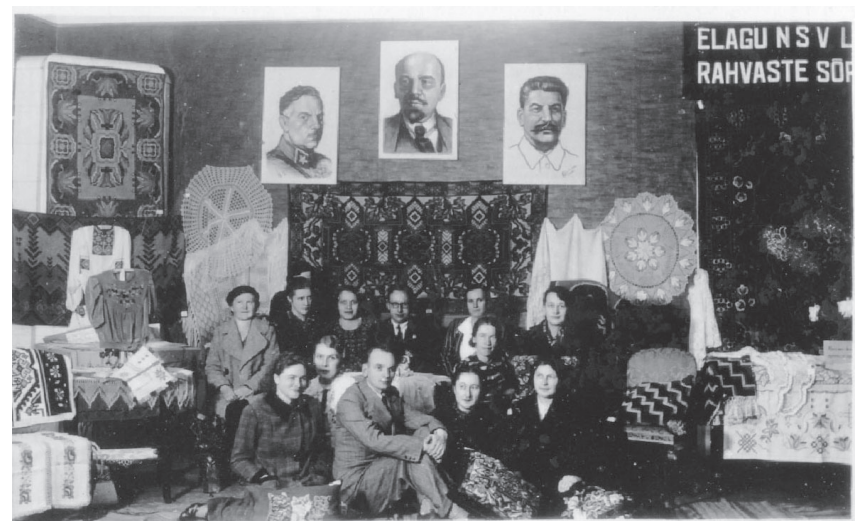

Photo 2. Women's handicraft exhibition in a Valga community house, with leaders and a banner saluting the "Friendship of the Nations" on the wall, 1940. Repro, Estonian History Museum (N15056).

82 Poola, M. Tutvustame vennasvabariike: Ungari ja Tadžiki NSV [Introducing Brotherly Republics: Hungary and the Tajik SSR]. (Eesti NSV Rahvaloomingu Maja klubitöö metoodika teadusliku kabineti väljaanne.) Tallinn, 1965.

83 Veskimägi, K.-O. Nõukogude unelaadne elu [Life as a Dream in the Soviet Union]. Tallinna Raamatutrükikoda, Tallinn, 1996, 327-329. 
Censorship in the Estonian SSR followed the same pattern. Veskimägi (1996, 327-329) describes censorship in Estonia, which started in 1940 and continued again from 1944, as a tool of russification, labelled as an effort to build up communism:

Building up communism and Moscow's aspirations are not one and the same thing - the first is the form and the latter is the content, i.e., to create an empire (to restore it in its former borders, increase and strengthen it. When the term internationalism was used, intentions of Russian chauvinism were meant) (ibid.).

In 1953, "Repertoire for Amateur Arts (Recommended List)" was published. ${ }^{84}$ In 1968, a translated all-union regulation - "Guidelines for the Preregistration of Concert and Other Mixed Programs" - by Moscow was issued, setting out rules for all professional and amateur collectives from January 1, 1968, and allowing Glavlit control over repertoire. ${ }^{85}$ Conforming to the rules for registering repertoires was mandatory. Scenarios of festivities and thematic evenings also had to get an approval from Glavlit. The selection of repertoire was checked. Special seats were reserved for executive committee inspectors and party officials at community house events. ${ }^{86}$

For the people working in community houses, surrounded by a multitude of administrative-inspective institutions, reports and approvals related to the tiniest of events (contents of a festive evening or a concert program) were a fact in daily soviet cultural work until the end of the occupation. In the 1960s, the censorship became more of a formality, but, as can be seen from many archive documents, during the era of high-Stalinism in 1945-1954, the reports of inspectors of the Committee for Organizations of Cultural Education were thorough and detailed. ${ }^{87}$

The reports the managers of community houses had to write for the Folk Art House $^{88}$ express the same attitude. What appears, reading these reports, is severe bureaucratic control and indoctrination of the Stalinist cultural canon during the first decades of the Soviet rule. Inspectors visited all community houses, checking their working plans, the activity books of hobby group leaders, event records, repertoires and Red Corners. Inspectors checked whether visual agitation outside of the community house worked (ibid.). Additionally, each community house had

84 Kunstilise isetegevuse repertuaar (soovitav nimekiri) [Repertoire for Amateur Arts (Recommended List)]. Ed. L. Levald. Eesti NSV Kultuuriministeeriumi Kunstide Peavalitsus, Eesti NSV Rahvaloomingu Maja kultuurharidustöö metoodiline keskkabinet, trükikoda "Kommunist", Tallinn, 1953.

85 NSVL kultuuriministri asetäitja V. Kuhharski käskkiri 8. dets. 1967. NSVL Ministrite Nõukogu 29. augusti 1967 määrus nr. 829. Juhend kontserdi- ja muude segaeeskavade eelregistreerimise korra kohta [Decree of the Deputy Minister of Culture of the Soviet Union, V. Kuhharski, about the Guidelines for the Preregistration of Concert and Other Mixed Programmes]. Tallinn, 1968.

86 Veldi, H. Imelik töö [Strange Work]. Haljala, 2012.

87 Documents of the Committee for Organizations of Cultural Education (1945-1953). ERA.R.1570.1.57; ERA.R.-1570.1.131; ERA.R.-1570.1.262; ERA.R.-1570.1.339; ERA.R.-1570.1.322.

88 Archival Documents of the Folk Art House (1940-1959). ERA.R.-28.2.87; ERA.R.-28.2.147; ERA.R.-28.2.151; ERA.R.-28.2.2.3. 
to carry out visual agitation tasks in the local agricultural organizations and also take care of topical banners and calls at the working locations of kolkhozes or sovkhozes. In addition, the inspectors of the Committee for Organizations of Cultural Education ${ }^{89}$ acquainted themselves with the reports on the cinematic and dancing evenings, with the educational level, social class and overall views of the workers of community houses. Furthermore, whether the work in community houses corresponded exactly to examples given in the guidelines was noted. Also censorship and inspections were carried out based on specific tasks. The task of the 1951 inspection, for example, was "to check and help the work of organizations of cultural education in relation to spring sowing and preparations for the 10th anniversary of the ESSR" (preparing for the Song Festival) (ibid.).

What appears from many reports ${ }^{90}$ is that the working conditions in community houses were often poor: buildings were old (several of them were built at the end of the 19th century), without heating or electricity. Reports reflect existential problems and shortages of money and other resources. Workers in community houses had to come up with the necessary means themselves. Later, when agriculture was on its feet, prosperous economic units helped to support Estonian community houses and also build relatively well-appointed cultural houses.

This reveals the priorities of the Moscow cultural policy: a centrally-funded system of cultural institutions together with the administrative bureaucracy, and the hordes of inspectors, censors, etc., was expensive for the government. There was a lack of the resources required to improve the working conditions in the community houses. It can also be seen as a pragmatic choice by the authorities. The Soviet regime gained the network of community houses, which was set up by people during the era of independent Estonia, without investing too much money into it.

However, after World War II, the new buildings for cultural centres (in the monumental Stalinist-style of architecture) were constructed by the Soviet authorities in Estonia also. According to the statistical overview by Uljas (1987) ${ }^{91}$, in 1940 there were 440 community houses in the state network of previous era, and in 1950 there were already 651 organizations of cultural education and clubs ${ }^{92}$

89 Archival Documents of the Committee for Organizations of Cultural Education (1950-1951). ERA.R.-1570.1.262; ERA.R.-1570.1.339; ERA.R.-1570.1.322.

90 Veldi, H. Imelik töö; Archival Documents of the Committee for Organizations of Cultural Education (1950-1951). ERA.R.-1570.1.262; ERA.R.-1570.1.339.

91 Uljas, J. Rahvamajad Eestis, 1920-1940 [Community Houses in Estonia, 1920-1940]. E. Vilde nim. Tallinna Pedagoogiline Instituut, Tallinn, 1987, 19, 28.

92 New soviet terms were implemented - community houses, in official documents, changed into clubs, cultural houses or organizations of cultural education. In Stalinist Estonia, the name community house was no longer suitable, since the era the term had stemmed from had to be erased from people's memory. While society houses and society movement as symbols of the Estonian civil society disappeared instantaneously in 1940 as the societies were dissolved, community houses made way to clubs and cultural houses in mid-1950s, during the heyday of Stalinism and the active defamation campaign and overall denigration of the Republic of Estonia. 
in the state network. Community houses were seen by the authorities first and foremost as an important ideological tool at grass-roots level until the end of the 1950s. It was because of the appearance of television (in 1955 saw the first program of Soviet Estonian broadcast), a new means of mass communication, which became the primary means of ideological work, and a number of clubs in Estonia did not increase any more. In 1961 there were 586 clubs. In 1970, the number of clubs was 435; in 1986 there were 336 cultural houses and in 1988 there were 323 cultural houses in Estonia (ibid.).

The archival documents of the Folk Art House in the 1960s (1966, 1967, 1973) and later, ${ }^{93}$ reveal that the general atmosphere in cultural education work became more liberal and politically less suppressive. Community houses with their everyday work and cultural activities still remained in the grip of the all-union system of censorship, control and ideological propaganda, but in the documents increasingly appeared the questions of raising the quality of amateur arts and the promotion of folk arts. The courses, seminars for specialists of cultural work choreographers, conductors, amateur theater directors, teachers of visual art and handicraft - dealt more with the improvement of special skills of specialists working in the community houses. Also, all kinds of local, national and all-union events, festivities, contests, were regularly organized by the central administration of folk art. Stalinist political indoctrination was gradually balanced by government-financed and organized leisure activities of people in the Soviet welfare state.

To summarize, many methodical materials were published right up to the collapse of the regime. In the guidelines, everyday activities of community houses were tied up and subordinated to the Five Year Plans' directions and plans of the Estonian Communist Party, which were subjected to the Moscow guidelines. Community houses were guided and controlled through regulations, guidelines, administration and censorship, reports and inspections on a regular basis. Community houses were sovietized and became tools in the hands of the authorities (the ECP), creating a new reality by spreading the Soviet cultural canon and socialist ideology. However, despite the heavy indoctrination and canonized frame for cultural practices, community houses also maintained their original function to provide space for amateur art practices, gatherings and leisure activities for many generations of Estonian population during the Soviet occupation.

\section{CONCLUSION}

Importing the Soviet coercive state practices, the authorities aimed to control and manipulate Estonian citizens in all spheres - even in leisure. People's free time self-expression was replaced by guided and coordinated cultural practices.

93 Archival Documents of the Folk Art House (1966, 1967, 1973). ERA.R.-28.2.318; ERA.R.28.2.338; ERA.R.-28.2.314; ERA.R.-28.2.369; ERA.R.-28.2.487. 
Extensive ideological rhetoric was used as mental oppression of people. An abrupt reversal in cultural norms and values caused a traumatic syndrome and double-mindedness in people. Sovietization changed the mental structure of the society - by suppressing the entrepreneurial spirit; this led to the mentality of state guardianship and alienation of people.

With the example of Estonian community houses, we can see how the network of cultural organizations of the first Republic of Estonia, with its roots in the 19th century civil activism of society, was subjected to governmental coercion by the totalitarian state. The Estonian well-developed network of cultural institutions suited the Soviet authorities, who adopted and sovietized the content and model of cultural policy. Within state-owned and centralized institutions, the Soviet cultural canon with local folklore variations was mediated through community houses to the population of Estonia.

Through the creation of a cultural canon, Soviet leaders sought to provide a set of shared values and common heritage of Soviet mass culture to form a common way of life - a monolithic Soviet society. The final aim of the Soviet cultural canon and cultural policy entailed a wide range of norms and practices intended to transform people's behaviour and create a new social order, a Soviet society and a Soviet person - a mass-man in an atomized society, as Arendt (1985, 318 323) has described. ${ }^{94}$

However, the main structures of the state model of the USSR established in the 1930s persisted until its collapse in 1991, but changed over time (being influenced by inner policies as well as external pressure of the Cold War). As it appeared from the archival documents and reports of the Folk Art House in the 1960s $(1966,1967,1973)$ and later, the general atmosphere in cultural work and education became more liberal and politically less suppressive.

Community houses with their everyday work and cultural activities still remained in the grip of the all-Union system of censorship, control and ideological propaganda, but in the documents increasingly appeared the questions of raising the quality of amateur arts and the promotion of folk arts. The courses, seminars for specialists of cultural work - choreographers, conductors, amateur theater directors, teachers of visual art and handicraft - dealt more with the improvement of skills of specialists working in the community houses. Also, all kinds of local, national and all-Union events, festivities and contests were regularly organized by the central administration of folk art. Stalinist political propaganda was gradually balanced by state-financed homogeneous and standardized leisure activities of people. Widely accessible, publicly funded leisure, folk and amateur art and homogeneous mass culture accounted for a substantial part of the closed Soviet society's "cultural" welfare state.

94 Arendt, H. The Origins of Totalitarianism. A Harvest Book, New York, 1948, 1985, 318-323. 


\section{EESTI RAHVAMAJADE SOVETISEERIMINE: NÕUKOGUDE KULTUURITÖÖ JUHENDID}

\section{Egge KULBOK-LATTIK}

Artiklis on uuritud Eesti kultuuri sovetiseerimist rahvamajade näitel, avades Nõukogude Liidu kultuuripoliitika ideoloogilisi eesmärke ja kultuurikaanoni kujunemist ning rakendamist okupeeritud Eestis.

19. sajandi viimasest veerandist alates hakati Liivimaal ja pisut hiljem ka Eestimaal kohalike inimeste ettevõtmisena seltsimaju rajama. ${ }^{95}$ Nende (hiljem rahvamajade) ehitamist tõukas tagant eestlaste kui maarahva kujunev kultuuriline emantsipatsioon, rahvusteadvus ja kogukondade vajadus oma avaliku ruumi ning kultuurikeskuste järele. Rahvamajad olid Eesti esimesed eelriiklikud omaalgatuslikult rajatud kultuuriasutused, kus kujunes laiem demokraatlik avalikkus. Uued kultuurilised praktikad - koorilaul, näitemäng, ühised peod eeskava ja tantsuõhtutega, raamatulaenutus ning üldharivad loengud, kõnekoosolekud, näitused jne tagasid rahvuslike ideede massilise leviku, millele tuginedes sai kujunev majanduslik ja poliitiline eliit esitada poliitilisi nõudmisi.

Eesti Vabariigi ajal (1918-1940) jätkusid nii seltsitegevus kui ka seltsimajade rajamine. Riik toetas nende ehitust soodsate laenudega, 1925. aastal loodi ka Eesti kultuurkapital. Hariduse- ja Sotsiaalministeeriumi ametniku Aleksander Kurvitsa ${ }^{96}$ eestvõttel tehti teoks idee luua rahvamajade riiklik võrk, mis sai oluliseks riiklikuks regionaalse kultuuripoliitika institutsiooniks. Rahvamajade seadus kinnitati 1931. aastal. 1938. aastal oli riiklikus rahvamajade võrgustikus üle 400 rahvamaja, neist 252 olid seltside ehitatud hooned ja 188 koolimajad, mida kasutati ka kultuurikeskusena.

Kui 1940. aastal okupeeris Nõukogude Liit Eesti, rakendati kultuurielu kujundamisel kohe leninlikke printsiipe ja läbiproovitud stsenaariume, mida enamlased olid 1917. aastast alates kasutanud kultuurirevolutsiooni eesmärkide saavutamisel Nõukogude Venemaal. Eesti kultuuri, mille institutsiooniline areng oli esimesel iseseisvusperioodil arenenud läänelikult moderniseeruva riigi halduspraktikate mõjul, asuti kavakindlalt sovetiseerima. Läänelik moderniseerumine asendus nõukoguliku modernsuse ja totalitaarse riigi praktikatega. Nõukogude Liidu kultuuripoliitika nägi riigi rolli kultuuris tellijana, ülalpidajana, eestkostja ja kontrollijana, kultuur oli ideoloogilise töö ning elanikkonna kasvatamise vahend. Artikli eesmärk on avada Eestis kohaldatud nõukogude kultuurikaanoni aspektid ja sovetiseerimise praktiline protsess. Artiklis on uuritud, kuidas riiklik sekkumine mõjutas elanikkonna töövälist harrastuskultuuri rahvamajades, mil moel õnnestus riigil seda suunata ja mis oli selle eesmärk.

95 Esimese seltsimaja Kanepis rajas 1887. aastal kohalik lauluselts.

96 Aleksander Kurvits (1896-1958), riigiametnik aastatel 1921-1940, panustas olulisel määral Eesti vabahariduse ja kultuuripoliitika arengusse. Eesti kultuuripoliitika uurijad võlgnevad Kurvitsale süsteemsed ülevaateväljaanded seadustest ja määrustest, mis reguleerisid kultuurielu ning vabahariduse toimimist (nt Kurvits, A. Eesti rahvaharidus ja kultuuriala korraldus. Haridusministeeriumi väljaanne, 1938). 
Eesti seltside ja rahvamajade elu muutis 23. augustil 1940 välja antud eraühingute riigistamise seadus ${ }^{97}$, mis hõlmas ka kõiki eramuuseumide, ühingute, seltside ning sihtasutuste ülalpidamisele kuuluvaid varasid. Seltside ja ühingute kogud, hooned (sh rahvamajad, muuseumid, teatrid jne) ning inventar anti üle Eesti NSV Hariduse Rahvakomissariaadile, kes nende varade ja hoonete põhjal asus sisse seadma riiklikult rahastatud kultuuriorganisatsioonide võrku.

Pärast II maailmasõda püüdis nõukogude võim muuta seni vabaalgatuslikult tegutsenud rahvamajad eeskätt poliitilise kasvatustöö ja kommunistliku ideoloogia kohalikeks agitatsiooni- ning propagandakeskusteks ja allutada need parteilisele juhtimisele. Seda tehti kohustusliku repertuaari, tsensuuri, kontrolli ja rahvamajade tööd juhtivate metoodiliste juhendite abil. Eriti rõhuv oli lauskontroll sõjajärgsel kõrgstalinismiperioodil (1945-1959), kui plahvatuslikult kasvas kultuuritööd juhtivate bürokraatlike institutsioonide hulk, mille juurutamine oli Nõukogude riigi halduspraktika üks eriomadusi. Bürokraatiat oli vaja tsensuuri ja kontrolli huvides, selle ülalhoidmiseks tegi riik märkimisväärseid kulutusi. Nõukogude impeeriumi kultuuripoliitika lõppeesmärk oli ideoloogiliselt suunatud massikultuuri abil kujundada nõukogude inimese identiteet ja homogeenne allutatud ühiskond.

Nõukogude riigi kultuuripoliitika põhijooned ja praktikad säilisid üldjoontes kuni impeeriumi lagunemiseni (1991), kuid need muutusid aja jooksul nii sisekui ka välispoliitiliste mõjurite tõttu vähem repressiivseteks. Arhiividokumentidest ilmneb, et stalinistlik kontroll ja parteipoliitiline propaganda Eesti rahvamajades asendus 1960. aastatel traditsiooniliste harrastuskultuuri praktikatega rahvatantsu, koorilaulu ja näitemänguga -, mida õpetasid koolitatud spetsialistid (tantsu-, näite- ning koorijuhid). Ideoloogiline surve vähenes ja asendus kvaliteedinõuetega riiklikult koolitatud spetsialistidele. Laialt kättesaadav, riiklikult rahastatud rahva- ja harrastuskultuur ühtsete standardiseeritud praktikatena moodustas olulise osa Nõukogude suletud ühiskonna "kultuurilisest" heaoluriigist.

97 RT 1940, 109, 1105. 1940. aastal tegutses Eestis 2200 vabahariduse- ja kultuuriseltsi 60000 70000 liikmega. 